\title{
Weed management in organic agriculture: are we addressing the right issues?
}

\author{
P BÀRBERI \\ Scuola Superiore Sant'Anna di Studi Universitari e di Perfezionamento, Pisa, Italy
}

Received 2 August 2001

Revised version accepted 12 December 2001

\section{Summary}

Despite the serious threat which weeds offer to organic crop production, relatively little attention has so far been paid to research on weed management in organic agriculture, an issue that is often approached from a reductionist perspective. This paper aims to outline why and how this problem should instead be tackled from a system perspective. Compared with conventional agriculture, in organic agriculture the effects of cultural practices (e.g. fertilization and direct weed control) on crop:weed interactions usually manifest themselves more slowly. It follows that weed management should be tackled in an extended time domain and needs deep integration with the other cultural practices, aiming to optimize the whole cropping system rather than weed control per se. In this respect, cover crop management is an important issue because of its implications for soil, nutrient, pest and weed management. It is stressed that direct (physical) weed control can only be successful where preventive and cultural weed management is applied to reduce weed emergence (e.g. through appropriate choice of crop sequence, tillage, smother/cover crops) and improve crop competitive ability (e.g. through appropriate choice of crop genotype, sowing/planting pattern and fertilization strategy). Two examples of system-oriented weed management systems designed for organic agriculture are illustrated as well as future perspectives and problems.

Keywords: allelopathy, biodiversity, cover crops, cultural weed control, system approach, weed prevention.

\section{Introduction}

Weeds are often recognized as the most serious threat to organic crop production (Penfold et al., 1995; Stonehouse et al., 1996; Clark et al., 1998), and fear of ineffective weed control is often perceived by farmers as one of the major obstacles to conversion from conventional to organic farming (Beveridge \& Naylor, 1999).

Despite this, researchers have so far paid relatively little attention to weed management-related issues in organic agriculture. Furthermore, weed management is often approached from a reductionist perspective, e.g. focusing only on the comparison between types and adjustments of implements for mechanical weed control in a given crop. This 'conventional' approach neglects the systemic ('holistic') nature of organic agriculture, which has long been recognized as a pillar for the design of real, effective organic crop production systems (Andrews et al., 1990; Lockeretz, 2000). In this respect, a too narrow view of weed management is questionable, because of the likely underestimation of interaction effects among system components and of their carryover across growing seasons, and may also result in information of little practical value to farmers.

The aim of this paper is to outline the reasons for and the potential benefits of tackling weed management in organic farming from a system perspective. After a reasoned analysis of the literature on this subject published recently, this paper illustrates how some peculiar features of organic systems suggest the need to undertake an integrated approach to weed management. Cover crop use is then presented as an important link between soil, crop, pest and weed management in organic systems. Two examples taken from recently published literature are reported to show the benefits of a system approach to weed management, i.e. the arrangement of a cropping system including an array of preventive, cultural and direct weed control methods. Lastly, future problems and perspectives of weed management in organic agriculture are outlined.

Correspondence: Dr Paolo Bàrberi, Scuola Superiore Sant'Anna di Studi Universitari e di Perfezionamento, Classe di Scienze Sperimentali, Settore di Scienze Agrarie, Piazza Martiri della Libertà 33, 56127 Pisa, Italy. Tel: (+39) 050883 449; Fax: (+ 39) 050883 215; E-mail: barberi@sssup.it 


\section{The present framework}

An analysis of the scientific literature published in major international sources in the period 1995-2000 has been carried out to reveal current research trends on issues related to weed management in organic agriculture. This analysis was based upon the outcome of several Current Contents (ISI, 2001) Boolean searches made by selecting: (1) 'organic' and 'weed'; (2) 'allelopathy' and 'weed'; (3) 'amendment' and 'weed'; (4) 'cover crop' and 'weed'; (5) 'cultivar' and 'weed'; (6) 'mulch' and 'weed', and (7) 'nonchemical' and 'weed' as keywords.

After clearance of the overlaps among search outcomes and of the occurrences clearly unrelated to organic farming, records were divided into 'reductionist' (i.e. those dealing with specific research issues out of a system framework), 'holistic' (i.e. those dealing with weed management in a system context) and 'other' (i.e. reviews and papers not clearly attributable to either of the previous groups). To have a clearer picture of the state of the art, occurrences included in each category were then classified by subject and crop. In both cases, the number of occurrences was higher than the actual number of papers because several papers dealt with multiple subjects and/or crops. Papers with subjects not specifically aimed at organic systems but suggesting potential applications were retained; for example, this was the case with some of the papers dealing with allelopathy, biological weed control, and cover crops and mulches.

A total of 115 papers dealing with weed management in organic agriculture was published in the period 19952000 (average 19.2 papers year $^{-1}$ ). This is quite a low figure, although the trend in the average number of papers published per year is increasing (data not shown). Only about one-third of these papers were clearly 'holistic', whereas $57 \%$ were 'reductionist', and $12 \%$ were classified as 'other' (Table 1). Cover crops and mulches were the most studied subjects $(19 \%$ of occurrences), followed by comparison between organic and conventional and/or integrated systems $(12 \%)$ and allelopathy $(8 \%)$. However, although the second issue

Table 1 Number of occurrences, divided by subject and typology*, retrieved by a literature search on weed management in organic agriculture (1995-2000)

\begin{tabular}{|c|c|c|c|c|}
\hline \multirow[b]{2}{*}{ Subject } & \multicolumn{4}{|c|}{ Typology of occurrence } \\
\hline & 'Reductionist' & 'Holistic' & Other $\dagger$ & Total \\
\hline Allelopathy & 14 & 1 & 2 & 17 \\
\hline Biodiversity & 0 & 3 & 1 & 4 \\
\hline Biological weed control & 3 & 0 & 0 & 3 \\
\hline Chemical vs. non-chemical weed control & 8 & 2 & 0 & 10 \\
\hline Conventional vs. low-input vs. organic systems & 2 & 23 & 0 & 25 \\
\hline Conversion to organic cropping/farming systems & 0 & 2 & 0 & 2 \\
\hline Cover crops and mulches & 30 & 4 & 4 & 38 \\
\hline Crop genotype & 6 & 0 & 2 & 8 \\
\hline Crop rotation & 0 & 4 & 3 & 7 \\
\hline Crop sowing (date, rate, pattern) & 2 & 0 & 1 & 3 \\
\hline Crop:weed competition & 4 & 0 & 3 & 7 \\
\hline Economics of weed management & 0 & 2 & 0 & 2 \\
\hline Energy efficiency of weed management & 0 & 1 & 0 & 1 \\
\hline Intercropping & 1 & 1 & 4 & 6 \\
\hline Mechanical weed control & 6 & 0 & 3 & 9 \\
\hline Soil amendments and fertilisers & 7 & 4 & 1 & 12 \\
\hline Soil quality & 1 & 5 & 0 & 6 \\
\hline Soil solarization & 1 & 0 & 1 & 2 \\
\hline Thermal weed control (e.g. flame weeding) & 2 & 0 & 1 & 3 \\
\hline Tillage system & 5 & 0 & 0 & 5 \\
\hline Weed population dynamics & 3 & 4 & 0 & 7 \\
\hline Weed seedbanks and weed seed germination & 3 & 1 & 0 & 4 \\
\hline Weed survey & 0 & 10 & 0 & 10 \\
\hline Weeds:insects interactions & 1 & 3 & 0 & 4 \\
\hline Weeds:pests:diseases interactions & 0 & 2 & 1 & 3 \\
\hline Others & 1 & 1 & 1 & 3 \\
\hline Total papers & 65 & 36 & 14 & 115 \\
\hline Total occurrences & 100 & 73 & 28 & 201 \\
\hline
\end{tabular}

*Based on the Current Contents database (ISI, 2001). Details on the search criteria used are reported in the text.

$\dagger$ Reviews and occurrences not clearly attributable to either 'reductionist' or 'holistic' categories. 
was obviously mainly approached from a 'holistic' perspective ( $92 \%$ of occurrences), both cover crops/mulches and allelopathy were mostly approached from a 'reductionist' perspective ( $79 \%$ and $82 \%$ of occurrences respectively), as well as other important subjects such as soil amendment and fertilization (58\%), soil tillage $(100 \%)$ and mechanical weed control $(67 \%)$. Ten occurrences $(5 \%$ of total) dealt with weed surveys conducted in organic cropping and farming systems.

Classification of papers according to crop is shown in Table 2. Nearly half the papers $(49 \%)$ involved studies on field crops, mainly winter cereals ( $21 \%$ of total), grain maize and sorghum (13\%), and rice $(8 \%)$. About one-third of the papers $(34 \%)$ dealt with vegetable crops, whereas studies on tree crops/shrubs and fodder crops represented $12 \%$ and $4 \%$ of the total respectively. In all but the last category, most of the studies were conducted in a reductionist context ( $>60 \%$ in the case of vegetable crops and tree crops/shrubs).
The results of this literature search show that researchers often tend to separate weed management and control from the overall context of organic systems management. The risk of this approach is that several important interactions among system components may be downplayed (if not neglected) or misunderstood, thus rendering the research outcome of little practical value.

\section{The necessity of studying crop:weed interactions in a long-term system perspective}

There is nowadays an increasing consensus on the idea that a thorough understanding of complex biological systems such as agro-ecosystems requires a system ('holistic') approach (Conway, 1987; Ikerd, 1993). Agro-ecosystems are complex entities made up of several components interacting with one another across space and time in such a way that their specific effects
Table 2 Number of papers, divided by cash crop and typology*, retrieved by a literature search on weed management in organic agriculture (1995-2000)

\begin{tabular}{|c|c|c|c|}
\hline \multirow[b]{2}{*}{ Cash crop } & \multicolumn{3}{|c|}{ Typology of paper } \\
\hline & 'Reductionist' & 'Holistic' & Total \\
\hline Grain maize and sorghum & 5 & 8 & 13 \\
\hline Oilseed rape & 0 & 1 & 1 \\
\hline Peanut & 1 & 0 & 1 \\
\hline Rice & 8 & 0 & 8 \\
\hline Soyabean & 0 & 1 & 1 \\
\hline Sugar beet & 2 & 1 & 3 \\
\hline Winter cereals (barley, oats, rye, wheat) & 11 & 10 & 21 \\
\hline Winter rape & 0 & 1 & 1 \\
\hline Field crops (total) & 27 & 22 & 49 \\
\hline Bell pepper & 3 & 0 & 3 \\
\hline Beans (Phaseolus spp.) & 2 & 3 & 5 \\
\hline Brassica spp. & 3 & 1 & 4 \\
\hline Carrot & 2 & 0 & 2 \\
\hline Faba bean & 1 & 0 & 1 \\
\hline Leek & 1 & 0 & 1 \\
\hline Onion & 4 & 0 & 4 \\
\hline Peas (Pisum spp.) & 1 & 1 & 2 \\
\hline Potato & 2 & 2 & 4 \\
\hline Strawberry & 0 & 2 & 2 \\
\hline Tomato & 2 & 4 & 6 \\
\hline Vegetable crops (total) & 21 & 13 & 34 \\
\hline Agroforestry systems & 1 & 0 & 1 \\
\hline Coffee & 1 & 0 & 1 \\
\hline Hop & 0 & 1 & 1 \\
\hline Orchards & 4 & 3 & 7 \\
\hline Tree nurseries & 2 & 0 & 2 \\
\hline Tree crops/shrubs (total) & 8 & 4 & 12 \\
\hline Fodder crops (leys and pastures) & 1 & 3 & 4 \\
\hline Total papers & 57 & 42 & 99 \\
\hline Total occurrences & 113 & 81 & 194 \\
\hline
\end{tabular}

*Based on the Current Contents (ISI, 2001) database. Details on the search criteria used are reported in the text. 
cannot easily be separated from the system itself. As a consequence, agro-ecosystems are recognized as independent dynamic entities possessing a behaviour of their own (Oberle \& Keeney, 1991; Pearson \& Ison, 1997).

Compared with conventional systems, organic agroecosystems have some peculiar features that enforce the need to study their components (including weeds and their management) in a global framework, i.e. by taking into account any possible interactions with the other system components occurring across space and time. In organic cropping systems, the effects of cultural practices on crop:weed interactions typically manifest themselves more slowly compared with conventional systems, both in the short (during a crop cycle) and in the long term (during one or more crop rotation cycles). Consequently, crop and weed management in organic agriculture should be tackled in an extended time domain and needs to be deeply integrated. Examples on crop fertilization and direct weed control are reported hereafter to explain why this is necessary.

\section{Crop fertilization}

Crop:weed interactions and weed community dynamics can be greatly influenced by crop fertilization strategy. Organic systems rely upon the use of organic fertilizers and amendments that typically release nutrients (especially $\mathrm{N}$ ) at a slower rate compared with mineral fertilizers (Magdoff, 1995). Nutrient release rate is largely dependent upon the $\mathrm{C}: \mathrm{N}$ ratio of the source, soil properties, climatic conditions and incorporation method, which together determine the mineralization rate of the organic matter incorporated in the soil (Bouldin et al., 1984; King, 1984; Maynard, 1993).

Faster nutrient release is often advantageous to weeds, which are usually able to take up nutrients in earlier growth stages more quickly and efficiently than crops (Jørnsgård et al., 1996; Liebman \& Davis, 2000), although this effect seems to turn into a competitive advantage only when initial weed stand density is high (Di Tomaso, 1995). Although slower nutrient release from organic sources should not result in increased weed competitive ability (Paul \& Beauchamp, 1993; Liebman \& Davis, 2000), it may favour the occurrence of lateseason weed emergence flushes that contribute to seedbank replenishment and consequently to higher weed seedling recruitment in subsequent years. For example, such an effect has been observed in the nitrophile species Stellaria media L. (Bastiaans \& Drenth, 1999). However, McCloskey et al. (1996) observed a decline in a $S$. media population over 3 years of application of poultry manure. The same authors also observed a negative effect of repeated organic fertiliza- tion on Sinapis arvensis L., whereas Galium aparine L. population density increased. In contrast, Stevenson et al. (1998) did not find any significant effects of fertilizer type on barley weed populations. Inconsistency of effects, sometimes also observed for the same species, suggests that broad generalizations on the effect of organic fertilizers on weed population dynamics should be avoided, as they may vary upon: (1) source of organic matter; (2) pedo-climatic conditions; and (3) relative species abundance in the weed community.

Additionally, organic amendments and fertilizers may represent a source of incoming viable weed seeds, e.g. when farmyard manure, composts or slurry have not been treated enough before their application to soil (Sances \& Ingham, 1997). Mt Pleasant \& Schlater (1994) observed that $1 \mathrm{~kg}$ of cattle manure contained up to 42 viable Chenopodium album L. seeds, and Zimdahl (1993) reported that, in the same weed species, about $20 \%$ of the seeds ingested by cattle were able to withstand passage in the rumen and subsequent manure preparation and storage. The use of composts may alleviate this problem, because temperatures reached during the composting phase are usually high enough to kill most weed seeds (De Luca \& De Luca, 1997). Complete loss of seed viability has been observed in several weed species after windrow composting of feedlot manure for 4 weeks (Tompkins et al., 1998) or of municipal wastes for > $3 \mathrm{~d}$ (Grundy et al., 1998), with temperatures ranging from 55 to $65{ }^{\circ} \mathrm{C}$. To achieve a significant reduction in seed viability, a base temperature above $46{ }^{\circ} \mathrm{C}$ seems to be required (Nishida et al., 1998), whereas the duration of composting appears to be less important (Ozores-Hampton et al., 1999). Also, storage of slurry in lagoons for a minimum period of 3 months can significantly reduce weed seed viability (Sartorato et al., 2001), and application of composted manure can substantially reduce weed emergence, especially of smallseeded species, because of physical and chemical (via the production of leachates) effects (Ligneau \& Watt, 1995). These leachates can also be produced in the windrow when the compost is kept constantly moist (Eghball \& Lesoing, 2000). It is worth mentioning that manure can also be used as a cheap substrate for the field introduction of fungi (e.g. Trichoderma spp.) used for biological weed control (Hutchinson, 1999).

Crop:weed competition and weed community dynamics may also be altered by fertilization management. Appropriate timing of $\mathrm{N}$ mineral fertilization has been proposed in integrated cropping systems as a mean to unbalance nutrient competition between crop and weeds to the benefit of the former. In practice, this approach implies prior knowledge of the weed flora that is likely to develop in a field: top-dressing $\mathrm{N}$ fertilization can conveniently be anticipated or delayed when late- or 
early-emerging species prevail respectively. Research on competition effects between sugar beet (Beta vulgaris $\mathrm{L}$. var. saccharata) and $S$. arvensis (an early-emerging species) or C. album (a late-emerging species) demonstrated the feasibility of this approach (Paolini et al., 1999). However, preliminary results of studies in which durum wheat (Triticum durum Desf.) competed with naturally occurring weed populations showed that this effect is not systematic but depends on seasonally variable climatic conditions, which in turn affect nutrient release in the soil and weed community composition (R Paolini \& P Bàrberi, unpubl. obs.). In organic systems, it is likely that this effect could be even less systematic, because the composition of organic fertilizers and amendments - especially of those produced on farm - typically varies between seasons, thereby representing an additional source of variation that influences nutrient release rates. Carry-over of nutrients from one growing cycle to the next should also be expected, especially when organic matter is applied in autumn or winter, when the mineralization rate of organic matter is low. As a consequence, the influence of organic fertilization on crop:weed relationships and weed population dynamics is probably present over a wider time period compared with mineral fertilization.

Variable composition of organic fertilizers and amendments makes it difficult to tailor a weed management strategy for organic farming using nutrient manipulation to improve crop competitive ability, although an exception might be represented by injection (side-dressing) of faster nutrient-releasing organic materials (e.g. slurry) at the sowing of row crops (Rasmussen, 2000).

The necessity of studying crop:weed interactions with a system approach also stems from the observation that nutrient management in organic farming is also intertwined with tillage system, as some organic amendments (e.g. manure) usually need to be ploughed down, whereas others (e.g. cover crops) can also be profitably managed with reduced tillage. Annual grasses, such as Alopecurus myosuroides Huds. (Cousens \& Moss, 1990) and Bromus sterilis L. (Froud-Williams, 1983), can be expected to increase with shallow incorporation of organic material in soil, because of their reduced seed dormancy and capability of emerging from only shallow soil depth. Moreover, small-seeded (e.g. Amaranthus spp.) and wind-dispersed (e.g. Sonchus spp.) weeds may find better opportunities to establish in minimum-tilled soil than in ploughed soil (Zanin et al., 1997; Bàrberi et al., 1998a). Similarly, reduced soil disturbance may favour biennial and perennial species, especially when organic matter is incorporated with PTO-powered rotary implements that cause fragmentation of vegetative propagules such as buds, rhizomes and tubers (Anderson, 1999). Perennial species such as Cirsium spp. and Elymus repens L. have been cited as troublesome weeds in organic farming systems in northern Europe (Rasmussen et al., 1999; Rydberg \& Milberg, 2000). It should remembered that the abundance of perennial weeds in these countries is also favoured by the widespread adoption of crop rotations in which the share of perennial leys (e.g. grass/clover), sometimes coupled with the use of catch crops, is quite high, usually above $50 \%$ (Olesen et al., 2000). Lack of primary tillage during the ley and catch crop phases, coupled with elimination of annual weeds by repeated mowing (Bulson et al., 1996), probably shifts weed community composition towards prevalence of vegetatively reproducing species.

Intensification of the studies on nutrient release dynamics and its relationship to crop management systems would help to clarify crop:weed interactions and weed community dynamics, two major steps necessary for the design of successful weed (and crop) management strategies in organic systems.

\section{Direct weed control}

Compared with herbicides, direct physical weed control (PWC) methods such as harrowing, hoeing or flaming are usually less effective, both in the short (within a growing cycle) and long term (across growing cycles).

Lower short-term effectiveness of PWC depends upon its reduced persistence of action and/or control. Whereas herbicides can persist in the soil for weeks (if not months in the case of residual herbicides), PWC may stimulate further weed emergence (in the case of mechanical weed control) or allow recovery from damage (in the case of both mechanical and thermal weed control, e.g. see Kurstjens \& Bleeker, 2000).

Soil disturbance caused by working implements brings new weed seeds close to the soil surface and may enhance soil $\mathrm{N}$ mineralization (Becker \& Böhrnsen, 1994) - both effects are conducive to subsequent weed emergence flushes. This effect, which is positive in the false seedbed technique as it helps to deplete the weed seedbank before crop sowing, is usually negative when it takes place during the crop cycle, especially when the crop is already too tall to allow any additional passes of the tool(s) used for mechanical weed control. Although recent technological advances such as torsion weeders (Ascard et al., 1999; Kurstjens \& Bleeker, 2000) or selfsteering hoes have shown promising results in both arable and vegetable crops, intrarow mechanical weed control remains problematic, leading to reduced overall effectiveness of PWC. Also, some weed species (e.g. grasses and other monocots) have morphological traits (e.g. the protection of the vegetative apex by folded young leaves) that make them less sensitive to heat 
damage (e.g. by flaming). Consequently, they may quickly recover from thermal stress, especially if they are large, thereby decreasing the overall treatment effectiveness (Ascard, 1994).

Limited effectiveness of PWC is also related to lower flexibility of non-chemical methods compared with chemical ones (at least, this holds for those crops for which herbicide choice is ample). Mechanical weed control is a viable option only within a certain range of soil conditions, the amplitude of which varies upon soil type and implement used (Bowman, 1997). For example, excessive soil moisture impedes field workability and may delay mechanical weed control until the crop is too high or weeds are too well developed. In the case of spring-tine harrowing, high soil moisture also increases the risk of crop damage (Peruzzi et al., 1997).

Compared with herbicide use, higher risk of incomplete weed control and lower systematicity of outcome usually results in lower long-term effectiveness of PWC, also related to a progressive build-up of the weed seedbank resulting from seed production by surviving or late-emerging weeds (Bastiaans \& Drenth, 1999). Out of a system context, it can then be expected that herbicides provide more effective and stable weed control than physical methods.

For this very reason, it is important not to rely on PWC as the only means of controlling weeds in organic systems, but to integrate it in an overall crop and weed management strategy arranged at the system scale. Integration of direct weed control with other cultural practices (crop and cultivar choice, tillage, fertilization, etc.) in a system context is the creed of integrated weed management systems (IWMS), which are recognized as the best approach to tackling weed problems anywhere (Swanton \& Weise, 1991; Zimdahl, 1995). This approach is even more important in organic systems, where herbicide use is forbidden.

\section{Building up a good weed management system}

Improvement in the effectiveness of PWC passes through the adoption of a global approach to weed problems. In practice, this means that PWC must necessarily rely on prior application of agronomic practices aimed to: (1) reduce weed emergence through the use of preventive methods (crop sequence choice, primary tillage, false seedbed technique, use of cover and/or smother crops); and (2) reduce weed competition through cultural methods that improve crop competitive ability (use of appropriate crop genotypes, transplants, sowing/planting pattern, fertilization strategy). Agronomic practices may preferentially exert the first or second effect or both (Table 3). Thus, theoretically, organic farmers have an ample arsenal of practices to include in an IWMS. Obviously, the choice of one practice instead of another depends upon pedo-climatic conditions, socio-economic constraints and farmers' risk perception (Gunsolus \& Buhler, 1999).

\section{Preventive methods}

It is not new to say that the foundations of successful weed management lie in an appropriate cropping system design. Maximum diversification of the cropping system (i.e. of crops and associated cultural practices), e.g. alternation between winter and summer crops, grain and root crops, nutrient-depleting and nutrient-building crops, as well as the inclusion of a ley phase, disrupt the regeneration niches of different typologies of weeds (annuals, biennials, perennials, obligate seasonal species), thereby preventing the establishment of a specialized flora and promoting that of a multifaceted weed community hosting numerous species each present at a low density (Buhler, 1999). It follows that crop rotations (in the strict sense) should rather be replaced by crop sequences without any rigid preplanned scheme in order to lower as much as possible the risk of weed adaptation to a repeated cultural regime. In this context, even a 'perfect' crop rotation would need to be modified from time to time.

Diversification of the crop sequence brings about the diversification of primary tillage (e.g. alternation between ploughing and non-inversion tillage), as well as of type and timing of seedbed preparation techniques (false seedbed technique, ridging) and cultivation. Combination of all these factors, which by themselves represent additional means of reducing weed emergence during a crop growing cycle, contributes to the long-term success of weed management in organic systems (Welsh et al., 1999).

Among preventive methods, the use of cover crops in organic systems merits a special mention because of their contribution to increased agro-ecosystem health (Lal et al., 1991). Owing to their beneficial effects on soil conservation, soil nutrient cycles, pest, pathogen and weed populations, cover crops can represent an ideal bridge between soil, nutrient, pests and weed management in an organic system and, as such, optimization of their use may be crucial for the success of the system itself.

Cover crop effects on weeds largely depend upon cover crop species and management, following cash crop and weed community composition (Bàrberi \& Mazzoncini, 2001). Prevention of weed emergence is exerted partly through competition for light, nutrients and soil moisture during the cover crop growing cycle, and partly through physico-chemical effects occurring 
Table 3 Classification of cultural practices potentially applicable in an integrated weed management system for organic farming, based on their prevailing effect (modified after Bàrberi, 2000)

\begin{tabular}{|c|c|c|c|}
\hline Cultural practice & Prevailing effect & Example & Main references \\
\hline Crop rotation & Reduction in weed emergence & $\begin{array}{l}\text { Alternation between winter } \\
\text { and spring-summer crops }\end{array}$ & $\begin{array}{l}\text { Karlen et al. (1994); Buhler } \\
\text { (1999); Welsh et al. (1999) }\end{array}$ \\
\hline Primary tillage & Reduction in weed emergence & $\begin{array}{l}\text { Deep ploughing, alternation } \\
\text { between ploughing and } \\
\text { reduced tillage }\end{array}$ & $\begin{array}{l}\text { Froud-Williams (1988); } \\
\text { McCloskey et al. (1996); } \\
\text { Bàrberi et al. (2001) }\end{array}$ \\
\hline Seedbed preparation & Reduction in weed emergence & False/stale-seedbed technique & Caldwell \& Mohler (2001) \\
\hline Cultivation & Reduction in weed emergence & $\begin{array}{l}\text { Post-emergence harrowing } \\
\text { or hoeing, ridging }\end{array}$ & $\begin{array}{l}\text { Rasmussen (1992); Bowman } \\
\text { (1997); Kurstjens et al. (2000) }\end{array}$ \\
\hline Cover crops & Reduction in weed emergence & $\begin{array}{l}\text { Cover crop grown in-between } \\
\text { two cash crops and used as } \\
\text { green manure or dead mulch }\end{array}$ & $\begin{array}{l}\text { Blum et al. (1997); Liebman \& } \\
\text { Davis (2000); Teasdale \& } \\
\text { Mohler (2000); Bàrberi } \\
\text { \& Mazzoncini (2001) }\end{array}$ \\
\hline Intercropping & $\begin{array}{l}\text { Reduction in weed emergence, } \\
\text { improvement in crop } \\
\text { competitive ability }\end{array}$ & $\begin{array}{l}\text { Cover crop used as living } \\
\text { mulch, intercropped cash crops }\end{array}$ & $\begin{array}{l}\text { Ofori \& Stern (1987); Liebman } \\
\text { \& Dyck (1993); Baumann et al. } \\
\text { (2000) }\end{array}$ \\
\hline $\begin{array}{l}\text { Thermal weed } \\
\text { control }\end{array}$ & Reduction in weed emergence & $\begin{array}{l}\text { Pre-emergence or localized } \\
\text { post-emergence flame-weeding }\end{array}$ & Ascard $(1994,1995)$ \\
\hline $\begin{array}{l}\text { Mulching/soil } \\
\text { solarization }\end{array}$ & Reduction in weed emergence & $\begin{array}{l}\text { Use of black or transparent } \\
\text { films (in glasshouse or field) }\end{array}$ & $\begin{array}{l}\text { Horowitz et al. (1983); } \\
\text { Sauerborn et al. (1989) }\end{array}$ \\
\hline Crop genotype & $\begin{array}{l}\text { Improvement in crop } \\
\text { competitive ability }\end{array}$ & $\begin{array}{l}\text { Use of cultivars characterized } \\
\text { by quick emergence, high } \\
\text { growth and soil cover rates in } \\
\text { early stages }\end{array}$ & $\begin{array}{l}\text { Lemerle et al. (1996, 2001); } \\
\text { Rasmussen \& Rasmussen } \\
\text { (2000); Olofsdotter (2001) }\end{array}$ \\
\hline Sowing/planting & $\begin{array}{l}\text { Improvement in crop } \\
\text { competitive ability }\end{array}$ & $\begin{array}{l}\text { Use of transplants, higher } \\
\text { seeding rate; lower } \\
\text { inter-row distance; anticipation } \\
\text { of, or delay in } \\
\text { sowing/transplant date }\end{array}$ & $\begin{array}{l}\text { Mohler (1996); Spandl et al. } \\
\text { (1998); Melander (2000) }\end{array}$ \\
\hline Fertilization & $\begin{array}{l}\text { Reduction in weed emergence, } \\
\text { improvement in crop } \\
\text { competitive ability }\end{array}$ & $\begin{array}{l}\text { Use of slow } \\
\text { nutrient-releasing } \\
\text { organic fertilizers and } \\
\text { amendments; fertilizer } \\
\text { placement }\end{array}$ & $\begin{array}{l}\text { Paolini et al. (1999); Liebman \& } \\
\text { Davis (2000); Rasmussen } \\
\text { (2000) }\end{array}$ \\
\hline Irrigation & $\begin{array}{l}\text { Reduction in weed emergence, } \\
\text { improvement in crop } \\
\text { competitive ability }\end{array}$ & $\begin{array}{l}\text { Irrigation placement } \\
\text { (micro/trickle-irrigation) }\end{array}$ & Berkowitz (1988) \\
\hline
\end{tabular}

when cover crop residues are left on the soil surface or ploughed down (Mohler \& Teasdale, 1993; Teasdale \& Mohler, 1993). For example, interference with weeds, including competition, physical and allelopathic effects, is usually higher when species of the Graminaceae and Cruciferae families are sown than with legume cover crops (Bodyston \& Hang, 1995; Blum et al., 1997), both in vivo and after cover crop destruction. Interference from cover crops and their residues is related to their capacity to occupy ecological niches otherwise available for weed development. This is mostly caused by the sequestration (into organic matter) of soil nutrients (especially $\mathrm{N}$ ), the release of allelochemicals and modifications in the soil microenvironment (Gallandt et al., 1999). For example, rye (Secale cereale L.) has been shown to possess both great $\mathrm{N}$ uptake capacity (Ditsch et al., 1993) and the potential for releasing allelopathic compounds (Putnam, 1988; Yenish et al., 1995).
Sorghum (Sorghum spp.) contains sorgoleone, a compound that has been proved to reduce weed emergence (Duke et al., 2000). Glucosinolates contained in living and dead tissues of kale (Brassica spp.), rocket (Eruca spp.) and mustard (Sinapis spp.) also have high allelopathic potential (Jimenez-Osornio \& Gleissman, 1987; Angelini et al., 1998). In contrast, the weed-suppressive ability of annual legumes such as crimson clover (Trifolium incarnatum L.) and subterranean clover (Trifolium subterraneum L.) is usually lower; this has been attributed to the stimulatory effect on weed emergence of $\mathrm{N}$ released from cover crop residues, especially when they are ploughed down (Blum et al., 1997). However, Teasdale \& Mohler (2000) claimed that, when cover crop residues are left to decompose on the soil surface, weed suppression results mostly from physical effects of the mulch rather than nutrient or allelochemical effects. In an attempt to model weed 
emergence as influenced by mulch physical properties, they showed that weed suppression was directly related to the mulch area index (mulch area divided by soil unit area), a parameter that varies considerably with the mulching material and greatly influences light extinction through the mulch (and consequently weed seed germination). The effect on the emergence of selected weed species was not uniform over a range of mulch masses: for example, the emergence of $A$. retroflexus was stimulated at low mulch masses $\left(<400 \mathrm{~g} \mathrm{~m}^{-2}\right)$ and subsequently reduced. Weed species sensitivity to mulch physical effects seems to be inversely related to seed mass, an effect also observed for sensitivity to allelochemicals (Liebman \& Davis, 2000).

In practice, the inclusion of cover crops in weed management strategies tailored to organic systems relies upon a better understanding of the interaction effects among cover crops features (species, cultivar, growth pattern) and their management (timing and method of killing and incorporation in soil, position in the cropping sequence) in different soil, climate and weed flora conditions.

In this respect, the importance of studying the interactions between weeds and other biota should also be stressed. For example, cover crops may influence insect population dynamics, e.g. providing a suitable habitat for the survival and reproduction of beneficial arthropods or - just like weeds - an alternative food source for arthropod pests (Norris \& Kogan, 2000). Also, cover crops may promote the establishment of specific soil biota, e.g. vesicular-arbuscular mychorrhizae, which, in turn, may drive weed population dynamics by favouring mychorrhizal plant species to the detriment of non-mychorrhizal species (Jordan et al., 2000).

\section{Cultural methods}

In this context, cultural weed management is referred to as the use of any methods that directly enhance crop competitive ability against weeds, i.e. methods applied during a crop growing cycle.

In this category, a first method is the use of crop genotypes that possess traits conferring a higher competitive ability against weeds. Usually, these traits are related to faster seedling emergence and canopy establishment (Rasmussen \& Rasmussen, 2000) and higher growth rates in early stages. In Australia, a genotype screening conducted on wheat showed that it is possible to select cultivars that possess competitive traits against weeds (e.g. Lolium rigidum Gaud.) while maintaining an adequate grain yield potential (Lemerle et al., 1996, 2001), although in most of them, the expression of competitive advantage is strongly influenced by environmental conditions (Lemerle et al., 2001). Here, it should be pointed out that not all traits that give crops a competitive advantage against weeds may usefully be exploited in cropping systems; for example, plant height, which is usually correlated with weed suppression (Benvenuti \& Macchia, 2000), is often negatively correlated with crop productivity and can also increase crop sensitivity to lodging, which may lead to severe yield losses. Higher crop competitive ability can also arise from the release of allelochemicals that inhibit weed emergence and growth. A study conducted on rice (Olofsdotter, 2001) showed that some cultivars are able to exert considerable allelopathic activity against weeds. Although the ranking of cultivars based on their allelopathic effect differed between field and laboratory trials (Table 4), there is potential for using genotype

Table 4 Weed suppressive ability of rice (Oryza sativa L.) cultivars under field conditions (dry seasons) compared with allelopathy screening under laboratory conditions (modified after Olofsdotter, 2001)

\begin{tabular}{|c|c|c|c|c|c|c|c|}
\hline \multirow[b]{2}{*}{ Cultivar } & \multicolumn{4}{|c|}{ Field experiments } & \multicolumn{3}{|c|}{ Laboratory screening } \\
\hline & $\begin{array}{l}\text { Weed } \\
\text { biomass } 1995 \\
\left(\mathrm{~g} \mathrm{~m}^{-2}\right)\end{array}$ & $\begin{array}{l}\text { Weed } \\
\text { biomass } 1996 \\
\left(\mathrm{~g} \mathrm{~m}^{-2}\right)\end{array}$ & $\begin{array}{l}\text { Weed tillers in } \\
\text { row } 1996 \\
\text { (no. } \mathrm{m}^{-1} \text { ) }\end{array}$ & $\begin{array}{l}\text { Biomass per } \\
\text { weed } \\
\text { (g per plant) }\end{array}$ & $\begin{array}{l}\text { Echinochloa } \\
\text { crus-galli root } \\
\text { length (mm) }\end{array}$ & SE & $\begin{array}{l}\text { Rank of whole } \\
\text { data set }\end{array}$ \\
\hline Lubang Red & 148 & 188 & 45 & 5.4 & 35.8 & 2.4 & 1 \\
\hline $\mathrm{YH} 1$ & 151 & 230 & 50 & 5.8 & 37.1 & 2.4 & 3 \\
\hline Musashikogane & 120 & 166 & 30 & 4.8 & 38.4 & 2.4 & 4 \\
\hline Taichung Native 1 & 129 & 274 & 64 & 5.3 & 42.6 & 2.4 & 5 \\
\hline Kouketsumuchi & 144 & 106 & 33 & 2.9 & 42.8 & 2.4 & 6 \\
\hline Takanenishiki & 141 & 126 & 29 & 3.9 & 46.6 & 2.4 & 14 \\
\hline AC 1423 & 116 & 219 & 42 & 7.2 & 46.8 & 0.9 & 15 \\
\hline Tan Gang & 134 & 91 & 30 & 2.6 & 47.0 & 2.6 & 17 \\
\hline IR38 (control) & 225 & 301 & 76 & 8.2 & 63.8 & 2.4 & 54 \\
\hline No-rice control & 289 & 460 & 122 & 12.6 & 97.0 & 0.8 & 111 \\
\hline Mean of all cvs & 187 & 281 & 57 & 7.6 & 58.9 & - & - \\
\hline SE & 26 & 49 & 10 & 1.5 & - & - & - \\
\hline CV & 28 & 35 & 35 & 40.0 & 26.0 & - & - \\
\hline
\end{tabular}


choice as a cultural tool in rice weed management strategies. So far, selection of weed-suppressive genotypes has mainly been considered as a way of reducing herbicide rates in integrated cropping systems; however, it is clear that this approach may be even more important for organic systems.

In any case, cultural methods are effective if they are able to maximize the differential of development between crop and weeds to the advantage of the former (Mohler, 1996). In this respect, an additional tool available to the farmer is the use of crop transplants instead of seeds, which is particularly important in vegetable crops that are often poor competitors against weeds. Besides the enhancement of crop competitive ability, use of transplants has been proposed in sugar beet as a mean to increase selectivity (i.e. the ratio between damage to weeds and crop) of intrarow weed control by torsion weeders (Melander, 2000). In this case, mechanical weed control can already be performed $5 \mathrm{~d}$ after transplanting, with little damage to the crop. However, a negative side-effect of transplant use in sugar beet is excessive root forking, although this may be overcome by optimizing the seedling raising technique.

In some cases, modification of crop sowing date, density and pattern may also reduce weed emergence and/or increase crop competitive ability (Mohler, 1996; Griepentrog et al., 2000). However, this effect cannot be generalized, as it is very much dependent upon crop species and location. For example, Spandl et al. (1998) observed that, compared with the autumn-sown crop, control of Setaria viridis (L.) Beauv. in spring-sown wheat increased because the weed tended to emerge in a single flush rather than in several flushes, thus becoming more sensitive to direct weed control methods. Obviously, in this case, the crop sowing date can be used as a weed management tool only in those environments where the farmer can actually choose whether to sow wheat in autumn or in spring and not, for example, in Mediterranean-type environments, where wheat can only be sown in autumn. In vining pea (Pisum sativum L.), an increase in the seeding rate may turn into a higher competitive ability, but often to the detriment of grain yield because of the concurrently higher intraspecific competition (Lawson \& Topham, 1985). Similarly, in potato (Solanum tuberosum L.), a higher planting density may turn into a crop competitive advantage but may also decrease tuber quality and increase crop susceptibility to diseases (Litterick et al., 1999). In contrast, in crops showing higher phenotypic plasticity, modification of seeding rates and/or pattern may have a better chance of being exploited in weed management strategies. For example, this is probably the case in pigeon bean (Vicia faba L. var. minor Peterm. Em. Hartz), a grain legume that is gaining interest in
Mediterranean organic cropping systems as a protein source for animal feed and a soil fertility-building crop. Pigeon bean can be sown either in narrowly spaced rows $(c .15 \mathrm{~cm}$ ) or in widely spaced rows (up to $70 \mathrm{~cm}$ ). In the first case, pod number and grain yield per plant decrease markedly and height of pod insertion on the stem increases, which reduces yield losses resulting from mechanical harvest. In both cases, grain yield per unit area and seed crude protein content are equally good (Bonari \& Macchia, 1975). Thanks to its phenotypic plasticity, it is likely that the seeding pattern (and consequently crop productivity) in organic pigeon bean may be optimized further, e.g. by sowing the crop in paired rows and using an inter-row distance $(c .40-50 \mathrm{~cm})$ that allows hoeing between the rows.

Another tool available to the organic farmer for increasing crop competitive ability against weeds is intercropping. Just like cover crops, intercrops increase the ecological diversity of farms and, by increasing the use of natural resources by the canopy compared with monocrops, often deprive weeds of the light, water and nutrients necessary for their development (Liebman \& Dyck, 1993). Use of intercropping may be seen more favourably by organic farmers than the use of cover crops (as living mulches) because, in the first case, all the component species are cash crops. Recently, Baumann et al. (2000) showed that, compared with sole crops, a leek:celery intercrop sown in a row-by-row replacement design decreased relative soil cover of weeds by $41 \%$ and, in another experiment, reduced the density and biomass of Senecio vulgaris L. by $58 \%$ and $98 \%$, respectively, mostly thanks to decreased light transmission through the canopy. Additionally, the intercrop gave a $10 \%$ yield increase compared with the sum of the yields given by sole crops. Weed suppression and crop yield increased in cereal:legume intercrops such as winter wheat:faba bean (Vicia faba L.) (Haymes \& Lee, 1999), winter wheat:pea (Paolini et al., 1993) and wheat:field beans (Phaseolus vulgaris L.) (Bulson et al., 1990). It is well known that, as in the case of living mulches, the success of intercropping relies upon fulfilling at best the requirements of the component species for natural resources (e.g. light interception and soil layers explored by crop root systems) in order to increase resource use complementarity and decrease interspecific competition. In practice, this means optimizing species spatial arrangement, their relative plant densities and their relative growth over time (Ofori \& Stern, 1987).

\section{Direct weed control methods}

The present boom in organic farming in industrialized countries has renewed the interest of agricultural 
machinery companies in the development of innovative tools for physical (especially mechanical and thermal) weed control. A review of the most notable technical innovations recently developed for direct weed control is beyond the scope of this paper. Technical issues related to mechanical and weed control are exhaustively treated by Bowman (1997), while in-depth discussion of issues related to thermal weed control can be found in Ascard (1995).

Most of the technical innovations developed recently in physical weed control are related to new equipment available for intrarow weed control in arable and vegetable crops. Among these, it is worth mentioning brush weeders (Melander, 1997; Fogelberg, 1998; Fogelberg \& Dock Gustavsson, 1999), finger weeders (Ascard \& Bellinder, 1996) and torsion weeders (Kurstjens \& Bleeker, 2000; Melander, 2000). Recent studies have shown that, in spring-tine harrowing (Kurstjens et al., 2000; Kurstjens \& Kropff, 2001), torsion weeding (Kurstjens \& Bleeker, 2000) and brush weeding (Fogelberg \& Dock Gustavsson, 1999), weed control is mostly dependent upon the uprooting of seedlings rather than their burial with soil. Generally, the effectiveness of mechanical weed control is very much influenced by soil type and conditions (especially soil moisture content), weed species composition and relative growth stage of crop and weeds (Rasmussen, 1992; Wilson et al., 1993; Rasmussen \& Ascard, 1995). Information on the suitability of each implement for different crops and pedo-climatic conditions is still incomplete, although it is by far the most widespread type of research conducted on mechanical weed control (see Table 1). However, just because of this dependency on site-specific conditions, research aimed only at finding the optimum technical adjustment of machinery for mechanical or thermal weed control may not always be of practical value to organic farmers. For example, it has been shown that soil, crop and weed conditions consequent to the use of ploughing or no tillage influenced the effectiveness of spring-tine harrowing in durum wheat to a much greater extent than any adjustments in tine angle (Bàrberi et al., 2000). For organic farming research, it is therefore strongly advisable to follow an approach aimed first at optimizing the system and only afterwards, within that system, to optimize specific cultural practices such as mechanical weed control.

High-tech solutions for physical weed control, such as 'electroporation' (i.e. the application of electric pulses to soil; Fogelberg, 2000), $\mathrm{CO}_{2}$ lasers (Heisel et al., 2001), precision guidance systems (Chamen, 2000) or crop and weed optical detection methods (Bontsema et al., 2000; Kielhorn et al., 2000), have already been developed. However, the enormous costs of some of this equipment make their widespread use very unlikely in real farm conditions, even for high-value cash crops. To date, the most urgent issues to be tackled in organic systems, at least in developed countries, are (1) to reduce the time needed for hand-weeding, which is sometimes up to $400 \mathrm{~h} \mathrm{ha}^{-1}$ or more (Vereijken et al., 1998; cited by Kropff et al., 2000; van Der Weide \& Bleeker, 2000); and (2) to make implements for direct weed control available to farmers at a reasonable price (Kropff et al., 2000).

\section{Towards 'holistic' weed management}

For the reasons outlined previously, fine-tuning of weed management strategies in organic agriculture must rely upon increased knowledge of (1) weed (and crop) ecology in a given agro-ecosystem, and (2) cropping system influence on weed population dynamics. Both types of information would allow a better understanding of those factors driving crop:weed interactions in specific organic farming systems. It is then germane that crop and weed management needs to be integrated, making full use of agro-ecological knowledge (Buhler, 1999). As a consequence, the concept of weed management per se becomes fuzzy, as it is not possible to disentangle it from cropping system management, in contrast to what usually happens in conventional agriculture. This system approach, although certainly perceived as important by weed scientists, is very rarely encountered in research papers. There are, however, a few notable exceptions, two of which are reported here to illustrate that weed management in organic agriculture can be successful when tackled in a global ('holistic') context. In these examples, the physical boundary of the system (and hence the term 'holistic') is referred to the field (case study 1) or the farm (case study 2).

\section{Case study 1: winter cereal:row crop 2-year rotation}

The first example is taken from Melander \& Rasmussen (2000) and refers to a 2-year rotation between a winter cereal and a row crop (sugar beet or a vegetable crop). This system has been developed for either integrated or organic cropping systems including a poorly competitive crop (the row crop). The aim of this weed management system is to stimulate weed emergence as much as possible (i.e. to deplete the weed seedbank) during the year in which the highly competitive crop (the cereal) is grown so that, in the following year, fewer weeds will emerge within the row in the poorly competitive crop. Winter wheat or barley is grown in the first year, leaving 25 -cm-wide unsown bands in between the cereal rows (Fig. 1). These bands are repeatedly hoed to stimulate the emergence of weed seedlings, which are destroyed by the following pass. In the next year, either sugar beet or a vegetable crop (e.g. kale, Brassica oleracea L. var. 
Year 1

Winter wheat

or spring barley

Row spacing:

12.5 and $25.0 \mathrm{~cm}$

Year 2

A row crop

(sugar beet or

a vegetable crop)

Fig. 1 A 2-year cropping system aimed at reducing in-row weed emergence in row crops (redrawn after Melander \& Rasmussen, 2000).

$\begin{array}{llllll}r & r & r & r & r & r \\ r & r & r & r & r & r \\ r & r & r & r & r & r \\ r & r & r & r & r & r \\ r & r & r & r & r & r \\ r & r & r & r & r & r\end{array}$

$\begin{array}{lll}r & r & r \\ r & r & r \\ r & r & r \\ r & r & r \\ r & r & r \\ r & r & r\end{array}$

acephala DC. subvar. laciniata L., or onion, Allium cepa L.) is drilled directly on these bands. Lack of soil ploughing in the second year avoids bringing new weed seeds up to the soil surface, an effect that would otherwise counteract the benefits of previous weed seedbank depletion.

With spring barley, the authors achieved an 81-92\% reduction in weed emergence compared with the previous year and a further $62-73 \%$ reduction in the case of prevention of seed shedding. However, with winter wheat, no appreciable weed emergence reduction was observed, probably because of a less susceptible weed flora compared with that emerging in spring-sown crops (barley or vegetable crops). Obviously, reduced in-row weed emergence in the second year cuts down the costs related to hand-weeding.

Although this management system is not completely 'holistic' (e.g., it does not involve nutrient management), it is clear that its strength is to frame the weed management strategy at the cropping system level by taking into account the interactions between crop sequence, soil tillage and weed management. The authors pointed out that this system needs to be improved in terms of: (1) the reduction in seed shedding in the unsown bands, especially from species with highly mobile seeds (e.g. Cirsium spp., Sonchus spp. and

$\begin{array}{ll}\gamma & \gamma \\ \gamma & \gamma \\ \gamma & \gamma \\ \gamma & \gamma \\ \gamma & \gamma \\ \gamma & \gamma\end{array}$

Taraxacum officinale Weber); and (2) the control of perennial weeds, which may take advantage of the lack of primary tillage in the second year.

\section{Case study 2: weed management system for organic onion production}

This second example has been taken from a paper by Nordell \& Nordell (1998) and is based on the work of two Pennsylvanian vegetable growers (the authors themselves).

Onion is a crop characterized by slow emergence and early growth which provides little soil cover and, as such, is highly sensitive to competition from weeds. It follows that weed management, especially in organic production, is usually perceived as highly problematic. Based on their practical experience, the authors have developed a cropping system in which several cultural practices are laid down in the 2-year period between the harvest of the previous vegetable crop and onion sowing, with the specific purpose of reducing weed emergence during the onion growing cycle (Fig. 2).

In the autumn after harvest of the preceding crop, a cereal cover crop (oats or rye) is sown and mowed repeatedly until it is ploughed down in the next spring. Mowing aims to impede seed shedding from annual
Fig. 2 Schematic representation of a 2-year whole-farm weed management system aimed at reducing weed emergence in organically grown onions (after Nordell \& Nordell, 1998).
YEAR 0 - Late summer: harvest of previous cash crop

- Autumn: sowing of grass cover crop

- Until next spring: repeated mowing<smiles>C1CCCC1</smiles>

YEAR 1 - Spring: cover crop is ploughed down

- Summer: soil harrowing every 2-3 wk

- Late summer: soil amended with composted horse manure

- Autumn: sowing of legume cover crop<smiles>C1CCCC1</smiles>

YEAR 2 - Spring: cover crop is disked in soil

- Spring: onion sowing 
weeds and to promote regrowth of the cereal, in order to achieve a consistent mulch effect over the season that inhibits weed development further. During the next summer, the soil is harrowed every 2-3 weeks to deplete the seedbank and bring propagules of perennial weeds up to the soil surface, where they are killed by heat and drought. In the late summer, composted horse manure produced on farm is incorporated in the soil. The authors claim that the use of this amendment, compared with fresh manure or fast nutrient-releasing organic fertilizers, is less stimulatory to weed emergence. In the early autumn of the second year, a legume cover crop (e.g. pea) is sown. This cover crop, besides enhancing soil fertility, further reduces annual weed growth over the following winter season. Lastly, this second cover crop is incorporated in the soil with a disc harrow just before onion transplanting. According to the authors, both weed incidence and hours needed for hand-weeding can be substantially reduced already after two or three cycles of this cropping system. The land surface yearly subtracted from cash crop growing using this system can be reduced by readjusting the crop rotation to limit the share of farm arable land actually cropped with onions in a given year.

Although this system is obviously not directly transferable to different agricultural environments, its approach could serve as a reference for developing similar cropping and farming systems elsewhere, based on the use of on-farm produced manure, locally adapted cover crop species and mechanical interventions optimized (in terms of type, frequency and timing) according to local crops and weed species abundance. This example shows that, where their use is not constrained by climatic factors, cover crops may represent an excellent link between soil, crop and weed management (another example of this kind can be found in Bàrberi et al., 1998b) and, as such, their inclusion in organic cropping systems should always be recommended.

\section{Future perspectives}

Many organic farmers are aware, at least instinctively, that successful weed management implies putting into practice the concept of maximum diversification of their cropping system, and on-farm experiences like the one just shown help to pinpoint this feeling. However, this task is often difficult to achieve, because practical solutions have to pass through local filters, such as soil and climate conditions, availability of and accessibility to external inputs (seeds, crop cultivars, machinery, etc.) and socio-economic constraints (market, tenure status, attitude towards entrepreneurial risk, etc.). From an agronomic viewpoint, it is possible to foresee a few issues having direct and indirect implications for weed management that may become important in the near future because of oncoming legislative constraints or their promising - yet only partially explored - perspectives for practical application. Three of these issues are taken as examples and discussed briefly here.

\section{Quality of organic seeds}

From 31 December 2003, in the European Union it will be compulsory to use organically produced seeds for sowing organic crops. At the moment, however, the demand for organic seed is much higher than its availability (Cook \& Wolfe, 2000). It can easily be predicted that weed control will be one of the main technical problems to be solved in organic seed crops. To avoid severe competition from weeds, these crops would require direct (mechanical or thermal) weed control to be often supplemented by hand-weeding, both at an early stage (to prevent negative effects on seed filling and, consequently, on germinability) and before harvest (to avoid weed seed shedding and consequent decrease in crop seed purity and increase in seed cleaning costs). It follows that the cost of organic seeds may become prohibitive, especially in the case of poorly competitive vegetable crops that would probably require more labour for hand-weeding. Besides this, low-quality, scarcely pure seeds might get to the market at a much lower cost and, as such, become attractive to farmers. These seeds would represent a source of weed infestation, leading to increased weed management problems for many subsequent years. In this perspective, while scientists are required to refine technical solutions aimed at reducing the costs of direct weed control (especially those related to hand-weeding), all the other actors involved in organic agricultural production (policymakers, organic farming certification bodies, extension services and farmers themselves) will have to take action to ensure easy access to good quality seeds at a reasonable price.

\section{Increasing biodiversity in agro-ecosystems}

It has long been recognized that, in agro-ecosystems, an increase in biodiversity at any level (crops, weeds, arthropods, soil microbes, etc.) usually results in better and more stable agro-ecosystem health and productivity (Andow, 1991; Altieri, 1995). Typically, organic farming promotes higher biodiversity compared with conventional farming (Soil Association, 2000; Stolton et al., 2000).

The use of cover crops and organic amendments, via the promotion of diversity in insect, fungal, bacterial or mychorrhyzal communities, may alter antagonist or competitive effects to the benefit of crops and to the 
detriment of weeds (Jordan et al., 2000; Liebman \& Davis, 2000; Norris \& Kogan, 2000). Once factors driving these effects are better understood, it might be possible to use this knowledge to improve organic weed management systems locally.

It would also be helpful to find indicators of 'functional' biodiversity, where weed species abundance is weighted on the role that they have in the agroecosystem (e.g. strong/weak competitors, promoters of the presence of beneficial arthropods, etc.). For example, highly competitive species could be assigned a different weighting than poorly competitive species, so that the overall diversity value (at the weed community level) might reflect these differences and consequently be evaluated from a more practical (i.e. farmer-wise) perspective.

\section{Allelopathy}

Management of allelopathy, defined here as 'any process that involves secondary metabolites produced by plants, algae, bacteria, and fungi that influence the growth and development of biological systems' (IAS, 1996), is another potential tool in the arsenal of the organic farmer. As mentioned before, several crops (some of which can be used as cover crops) have been proved to release allelopathic compounds in the soil (Inderjit \& Keating, 1999), many of which have been chemically characterized (Inderjit, 1996; Seigler, 1996; Waller et al., 1999). The idea of exploiting these compounds as 'natural herbicides' is therefore very appealing (Putnam, 1988; Weston, 1996; Duke et al., 2000). However, the large majority of the studies carried out on this topic have referred to 'reductionist' trials carried out in controlled environments (see Table 1), often with the only aim to extract and characterize allelochemicals or, at the most, to test the effect of these compounds on the germination of selected sensitive species in bioassays. In the case of crop:weed interactions, absolute evidence of the occurrence of allelopathy in the field is difficult to obtain, mainly because allelopathic effects are difficult to disentangle from resource competition and other biotic effects (Qasem \& Hill, 1989; Weidenhamer, 1996; Inderjit \& del Moral, 1997). Additionally, the production and release of allelochemicals depend largely upon environmental conditions, usually being higher when plants are under stress, e.g. extreme temperatures, drought, soil nutrient deficiency, high pest incidence (Einhellig, 1987); also, the range and concentration of chemicals that a given species can produce can vary accordingly (Anaya, 1999). Other effects that need to be examined are allelopathy-mediated weed:weed, weed:crop and crop:following (or companion) crop interactions. It is therefore questionable whether allelopathy management per se would ever represent a consistently effective weed management tool; however, a better understanding of allelopathic occurrence in field situations, and of how it is influenced by cultural practices, would make it possible to include allelopathic crops in organic cropping systems and use them as a complementary tactic in a weed management strategy.

\section{Conclusions}

It is highly desirable that examples of system-based approaches to weed management in organic farming should become more common in the international scientific literature. One of the main reasons for the existence of this gap is possibly the conflict between the need for implementing long-term research (which is particularly important in an organic context) and the constraints posed by short-term research funding (Lockeretz, 2000). Additionally, researchers need to overcome their reluctance to carry out long-term studies, only partly arising from methodological difficulties. Modelling crop:weed interactions and weed population dynamics might help to bridge this gap (Kropff et al., 2000), but model outputs would always have to be validated with results coming from ongoing long-term field experiments.

However, it should be stressed that 'reductionist' and 'holistic' research are not mutually exclusive; rather, they should complement each other. An ideal approach to weed management in organic farming should be one that includes two subsequent steps: (1) adjustment of the cropping system in order to reduce weed emergence and the abundance of selected troublesome species ('holistic' step); (2) fine-tuning of direct weed control methods (harrowing, hoeing, thermal weed control, etc.) within the scenario set up previously ('reductionist' step).

Last but not least, it should be kept in mind that, given the dynamic nature of agro-ecosystems, even optimized weed management systems would probably require some readjustment after a period of time; this is another reason why long-term, system-based experiments are particularly important in organic agriculture.

\section{References}

Altieri MA (1995) Toward sustainable agriculture. In: Agroecology The Science of Sustainable Agriculture (ed. MA Altieri), 367-379. Westview Press, Boulder, CO, USA.

ANAYA AL (1999) Allelopathy as a tool in the management of biotic resources in agroecosystems. Critical Reviews in Plant Science 18, 697-739. 
Anderson WP (1999) Perennial Weeds. Characteristics and Identification of Selected Herbaceous Species (ed. WP Anderson). Iowa State University Press, Ames, IA, USA.

Andow D (1991) Vegetational diversity and arthropod population response. Annual Review of Entomology 36, 561-586.

Andrews RW, Peters SE, Janke RR \& Sahs WW (1990) Converting to sustainable farming systems. In: Sustainable Agriculture in Temperate Zones (eds CA Francis, CB Flora \& LD King), 281-313. John Wiley \& Sons, New York, USA.

Angelini L, Lazzeri L, Galletti S, Cozzani A, Macchia M \& PAlmieri S (1998) Antigerminative activity of three glucosinolate-derived products generated by mirosinase hydrolisis. Seed Science and Technology 26, 771-780.

AsCARD J (1994) Dose-response models for flame weeding in relation to plant size and density. Weed Research 34, 377-385.

Ascard J (1995) Thermal Weed Control by Flaming. PhD Thesis, Swedish University of Agricultural Sciences, Alnarp, Sweden.

Ascard J \& Bellinder RR (1996) Mechanical in-row cultivation in row crops. In: Proceedings 2nd International Weed Control Congress, Copenhagen, Denmark, 1121-1126.

Ascard J, Olstedt N \& Bengtsson H (1999) Mechanical weed control using inter-row cultivation and torsion weeders in vining pea. In: Proceedings 11th EWRS Symposium, Basle, Switzerland, 119.

BÀrberi P (2000) Il controllo integrato delle infestanti nelle colture orticole. L'informatore Agrario 21, 91-97 (in Italian).

BÀrberi P \& MAZzoncini M (2001) Changes in weed community composition as influenced by cover crop and management system in continuous corn. Weed Science 49, 491-499.

Bàrberi P, Cozzani A, Macchia M \& Bonari E (1998a) Size and composition of the weed seedbank under different management systems for maize continuous crop. Weed Research 38, 319-334.

Bàrberi P, Caporali F, Campiglia E \& Mancinelli R (1998b) Weed community composition in a mixed farming system in Central Italy. In: Proceedings of the Workshop: Mixed Farming Systems in Europe (eds H van Keulen, EA Lantinga \& HH van Laar), A P Minderhoudhoeve-reeks no. 2, 71-77. Landbouwuniversiteit Wageningen, Dronten, The Netherlands.

Bàrberi P, Silvestri N, Peruzzi A \& Raffaelli M (2000) Finger harrowing of durum wheat under different tillage systems. Biological Agriculture and Horticulture 17, 285-303.

BÀrberi P, Bonari E \& Mazzoncini M (2001) Weed density and composition in winter wheat as influenced by tillage systems. Proceedings 1st World Congress on Conservation Agriculture, Madrid, Spain, 451-455.

BastiaAns L \& Drenth H (1999) Late-emerging weeds; phenotypic plasticity and contribution to weed population growth. In: Proceedings 11th EWRS Symposium, Basle, Switzerland, 3.

BAUMANN DT, KRopfF MJ \& BastiaAns L (2000) Intercropping leeks to suppress weeds. Weed Research 40, 359-374.

Becker K \& BöHrnsen A (1994) Wirkungen mechanischer Pflegemaßnahmen auf die Unkrautabundanz und die Nmineralisation im Boden. Zeitschrift für Pflanzkrankheiten und Pflanzschutz 14, 315-324 (in German with English abstract).
Benvenuti S \& Macchia M (2000) Role of durum wheat (Triticum durum Desf.) canopy height on Sinapis arvensis L. growth and seed production. In: Proceedings XIème Colloque International sur la Biologie des Mauvaises Herbes, Dijon, France, 305-312.

Berkowitz AR (1988) Competition for resources in weed-crop mixtures. In: Weed Management in Agroecosystems: Ecological Approaches (eds MA Altieri \& M Liebman), 89-119. CRC Press, Boca Raton, FL, USA.

BeVERIDGe LE \& NAYlor REL (1999) Options for organic weed control - what farmers do. In: Proceedings 1999 Brighton Conference - Weeds, Brighton, UK, 939-944.

Blum U, King LD, Gerig TM, Lehman ME \& Worsham AD (1997) Effects of clover and small grain cover crops and tillage techniques on seedling emergence of some dicotyledonous weed species. American Journal of Alternative Agriculture 4, 146-161.

Bodyston RA \& Hang A (1995) Rapeseed (Brassica napus) green manure crop suppresses weeds in potato (Solanum tuberosum). Weed Technology 9, 669-675.

BONARI E \& MACCHIA M (1975) Effetto dell'investimento sulla produzione del favino (Vicia faba L. var. minor Peterm Beck). Rivista di Agronomia 9, 416-423 (in Italian with English abstract).

Bontsema J, Van Asselt CJ \& Vermeulen GD (2000) Intrarow weed control. In: Proceedings 4th Workshop of the EWRS Working Group on Physical and Cultural Weed Control, Elspeet, The Netherlands, 55.

Bouldin DR, Klausner SD \& Reid WS (1984) Use of nitrogen from manure. In: Nitrogen in Crop Production (ed. RD Hauck), 221-245. ASA-CSSA-SSSA, Wisconsin, USA.

Bowman G (1997) Steel in the Field: A Farmer's Guide to Weed Management Tools (ed. G Bowman), Handbook Series no. 2. Sustainable Agriculture Network, Beltsville, USA.

Buhler DD (1999) Expanding the context of weed management. In: Expanding the Context of Weed Management (ed. DD Buhler), 1-7. The Haworth Press, New York, USA.

Bulson HAJ, SnAydon RW \& Stopes CE (1990) Intercropping autumn-sown beans and wheat: effects on weeds under organic farming conditions. In: Crop Protection in Organic and Low Input Agriculture (ed. R Unwin), 55-62. British Crop Protection Council, Bracknell, UK.

Bulson HAJ, Welsh JP, Stopes CE \& Woodward L (1996) Agronomic viability and potential economic performance of three organic four year rotations without livestock 19881995. Aspects of Applied Biology 47, Rotations and Cropping Systems, 277-286.

Caldwell B \& Mohler CL (2001) Stale seedbed practices for vegetable production. Hortscience 36, 703-705.

Chamen WCT (2000) A new methodology for weed control and cereal crop production based on wide span vehicles and precision guidance: Biotrac. In: Proceedings 4th Workshop of the EWRS Working Group on Physical and Cultural Weed Control, Elspeet, The Netherlands, 51-54.

Clark MS, Ferris H, Klonsky K, Lanini WT, Van Bruggen AHC \& Zalom FG (1998) Agronomic, economic, and environmental comparison of pest management in conventional and alternative tomato and corn systems in Northern California. Agriculture Ecosystems and Environment 68, 51-71. 
Conway GR (1987) The properties of agroecosystems. Agricultural Systems 24, 95-117.

Cook A \& Wolfe M (2000) Production of organic seed for the organic farming sector. In: Proceedings 13th International IFOAM Scientific Conference, Basle, Switzerland, 218-221.

Cousens R \& Moss SR (1990) A model of the effects of vertical distribution of weed seeds within the soil. Weed Research $\mathbf{3 0}$, $61-70$.

De Luca TH \& De Luca DK (1997) Composting for feedlot manure management and soil quality. Journal of Production Agriculture 10, 235-241.

Di Tomaso JM (1995) Approaches for improving crop competitiveness through the manipulation of fertilization strategies. Weed Science 43, 491-497.

Ditsch DC, Alley MM, Kelley KR \& Lei YZ (1993) Effectiveness of winter rye for accumulating residual fertilizer $\mathrm{N}$ following corn. Journal of Soil and Water Conservation 48, 125-132.

Duke SO, Dayan FE, Romagni JG \& Rimando AM (2000) Natural products as sources of herbicides: current status and future trends. Weed Research 40, 99-111.

Eghball B \& Lesoing GW (2000) Viability of weed seeds following manure windrow composting. Compost Science and Utilization 8, 46-53.

EINHELLIG FA (1987) Interaction among allelochemicals and other stress factors of the plant environment. In: Allelochemicals, Role in Agriculture and Forestry (ed. GR Waller), 343-357. ACS Symposium Series, Vol. 330. American Chemical Society, Washington DC, USA.

Fogelberg F (1998) Physical Weed Control - Intra-Row Brush Weeding and Photocontrol in Carrots. PhD Thesis, Swedish University of Agricultural Sciences, Alnarp, Sweden.

Fogelberg F (2000) Electroporation - can we control weed seeds by the use of electric pulses applied in soil? In: Proceedings 4th Workshop of the EWRS Working Group on Physical and Cultural Weed Control, Elspeet, The Netherlands, 50 .

Fogelberg F \& Dock Gustavsson A-M (1999) Mechanical damage to annual weeds and carrots by in-row brush weeding. Weed Research 39, 469-479.

Froud-Williams RJ (1983) The influence of straw disposal and cultivation regime on the population dynamics of Bromus sterilis. Annals of Applied Biology 103, 139-148.

Froud-Williams RJ (1988) Changes in weed flora with different tillage and agronomic management systems. In: Weed Management in Agroecosystems Ecological Approaches (eds MA Altieri \& M Liebman), 213-236. CRC Press, Boca Raton, FL, USA.

Gallandt ER, Liebman M \& Huggins DR (1999) Improving soil quality: implications for weed management. In: Expanding the Context of Weed Management (ed. DD Buhler), 95-121. The Haworth Press, New York, USA.

Griepentrog HW, Weiner J \& Kristensen L (2000) Increasing the suppression of weeds by varying sowing parameters. In: Proceedings 13th International IFOAM Scientific Conference, Basle, Switzerland, 173.

Grundy AC, Green JM \& Lennartsson M (1998) The effect of temperature on the viability of weed seeds in compost. Compost Science and Utilization 6, 26-33.
Gunsolus JL \& Buhler DD (1999) A risk management perspective on integrated weed management. In: Expanding the Context of Weed Management (ed. DD Buhler), 167-187. The Haworth Press, New York, USA.

Haymes R \& LeE HC (1999) Competition between autumn and spring planted grain intercrops of wheat (Triticum aestivum) and field bean (Vicia faba). Field Crops Research 62, 167-176.

Heisel T, Schou J, Christensen S \& Andreasen C (2001) Cutting weeds with a $\mathrm{CO}_{2}$ laser. Weed Research 41, 19-29.

Horowitz M, Regev Y \& Herzlinger G (1983) Solarization for weed control. Weed Science 31, 170-179.

Hutchinson CM (1999) Trichoderma virens-inoculated composted chicken manure for biological weed control. Biological Control 16, 217-222.

IAS (1996) International Allelopathy Society (IAS). Constitution and Bylaws. In: Proceedings First World Congress on Allelopathy: A Science for the Future, Cádiz, Spain.

IKERD JE (1993) The need for a system approach to sustainable agriculture. Agriculture Ecosystems and Environment 46, 147-160.

InDERJIT (1996) Plant phenolics in allelopathy. Botanical Review 62, 186-202.

INDERJIT \& DEL MORAL R (1997) Is separating resource competition from allelopathy realistic? Botanical Review 63, 221-230.

InDERJit \& KeAting KI (1999) Allelopathy: principles, procedures, processes, and promises for biological control. Advances in Agronomy 67, 141-232.

ISI (2001) Current Contents. Institute for Scientific Information, Philadelphia, USA.

Jimenez-Osornio JJ \& Gleissman SR (1987) Allelopathic interference in a wild mustard (Brassica campestris L.) and broccoli (Brassica oleracea L. var. italica) intercrop agroecosystem. In: Allelochemicals, Role in Agriculture and Forestry (ed. GR Waller), 262-274. ACS Symposium Series, Vol. 330. American Chemical Society, Washington DC, USA.

Jordan NR, Zhang J \& Huerd S (2000) Arbuscularmychorrhizal fungi: potential roles in weed management. Weed Research 40, 397-410.

Jørnsgård B, Rasmussen K, Hill J \& Christiansen LJ (1996) Influence of nitrogen on competition between cereals and their natural weed populations. Weed Research 36, 461-470.

Karlen DL, Varvel GE, Bullock DG \& Cruse RM (1994) Crop rotations for the 21 st century. Advances in Agronomy 53, 1-45.

Kielhorn A, Dzinaj T, Gelze F et al. (2000) Beikrautregulierung in Reihenkulturen - sensorgesteuerte Querhacke in Mais. Zeitschrift für Pflanzkrankheiten und Pflanzschutz 17, 207-216 (in German with English abstract).

KING LD (1984) Availability of nitrogen in municipal, industrial, and animal wastes. Journal of Environmental Quality 13, 609-612.

KropfF MJ, Baumann DT \& BastiaAns L (2000) Dealing with weeds in organic agriculture - challenge and cutting edge in weed management. In: Proceedings 13th International IFOAM Scientific Conference, Basle, Switzerland, 175-177.

Kurstjens DAG \& Bleeker P (2000) Optimising torsion weeders and finger weeders. In: Proceedings 4th Workshop of the EWRS Working Group on Physical and Cultural Weed Control, Elspeet, The Netherlands, 30-32. 
Kurstjens DAG \& KropfF MJ (2001) The impact of uprooting and soil-covering on the effectiveness of weed harrowing. Weed Research 41, 211-228.

Kurstjens DAG, Perdok UD \& Goense D (2000) Selective uprooting by weed harrowing on sandy soils. Weed Research 40, 431-447.

Lal R, Regnier E, Eckert DJ, Edwards WM \& Hammond R (1991) Expectations of cover crops for sustainable agriculture. In. Cover Crops for Clean Water (ed. WL Hargrove), 1-11. Soil and Water Conservation Society Publication, Ankey, USA.

LAwson HM \& Topнam PB (1985) Competition between annual weeds and vining peas grown at a range of population densities: effects on the weeds. Weed Research 25, 221-229.

Lemerle D, Verbeek B, Cousens RD \& Coombes NE (1996) The potential for selecting wheat varieties strongly competitive against weeds. Weed Research 36, 505-513.

Lemerle D, Verbeek B \& Orchard B (2001) Ranking the ability of wheat varieties to compete with Lolium rigidum. Weed Research 41, 197-209.

Liebman M \& Davis AS (2000) Integration of soil, crop, and weed management in low-external-input farming systems.

Weed Research 40, 27-47.

Liebman M \& Dyck E (1993) Crop rotation and intercropping strategies for weed management. Ecological Applications 3, 92-122.

LigneAu LAM \& WATT TA (1995) The effects of domestic compost upon the germination and emergence of barley and six arable weeds. Annals of Applied Biology 126, 153-162.

Litterick AM, Redpath J, Seel W \& Leifert C (1999) An evaluation of weed control strategies for large-scale organic potato production in the UK. In: Proceedings 1999 Brighton Conference - Weeds, Brighton, UK, 951-956.

LockereTz W (2000) Organic farming research, today and tomorrow. In: Proceedings 13th International IFOAM Scientific Conference, Basle, Switzerland, 718-720.

McCloskey M, Firbank LG, Watkinson AR \& Webb DJ (1996) The dynamics of experimental arable weed communities under different management practices. Journal of Vegetation Science 7, 799-808.

Magdoff F (1995) Soil quality and management. In: Agroecology. The Science of Sustainable Agriculture (ed. MA Altieri), 349-364. Westview Press, Boulder, CO, USA.

MAYnARd A (1993) Nitrate leaching from compost-amended soils. Compost Science and Utilization 1, 65-72.

Melander B (1997) Optimization of the adjustment of a vertical axis rotary brush weeder for intra-row weed control in row crops. Journal of Agricultural Engineering Research 68, 39-50.

Melander B (2000) Mechanical weed control in transplanted sugar beet. In: Proceedings 4th Workshop of the EWRS Working Group on Physical and Cultural Weed Control, Elspeet, The Netherlands, 25.

Melander B \& Rasmussen K (2000) Reducing intrarow weed numbers in row crops by means of a biennial cultivation system. Weed Research 40, 205-218.

MoHLer CL (1996) Ecological bases for the cultural control of annual weeds. Journal of Production Agriculture 9, 468-474.

Mohler CL \& Teasdale JR (1993) Response of weed emergence to rate of Vicia villosa Roth and Secale cereale $\mathrm{L}$. residue. Weed Research 33, 487-499.
Mt Pleasant J \& Schlater KJ (1994) Incidence of weed seed in cow (Bos spp.) manure and its importance as a weed source for cropland. Weed Technology 8, 304-310.

Nishida T, Shimizu N, Ishida M, Onoue T \& Harashima N (1998) Effect of cattle digestion and of composting heat on weed seeds. Japanese Agricultural Research Quarterly 32, $55-60$.

Nordell A \& Nordell E (1998) A whole-farm approach to weed control. A strategy for weed-free onions. In: Proceedings of the Conference: Sharing the Lesson of Organic Farming, Guelph, Canada.

Norris RF \& Kogan M (2000) Interactions between weeds, arthropod pests, and their natural enemies in managed ecosystems. Weed Science 48, 94-158.

Oberle SL \& KeENEy DR (1991) A case for agricultural systems research. Journal of Environmental Quality 20, 4-7.

Ofori F \& STERN WR (1987) Cereal-legume intercropping systems. Advances in Agronomy 41, 41-90.

Olesen JE, Askegaard M \& Rasmussen IA (2000) Design of an organic farming crop rotation experiment. Acta Agriculturae Scandinavica - Section B, Soil and Plant Science 50, 13-21.

Olofsdotter M (2001) Rice - a step toward use of allelopathy. Agronomy Journal 93, 3-8.

Ozores-Hampton M, Stoffella PJ, Bewick TA, Cantliffe DJ \& OBREZA TA (1999) Effect of age of cocomposted MSW and biosolids on weed seed germination. Compost Science and Utilization 7, 51-57.

Paolini R, Caporali F \& Campiglia E (1993) Yield response, complementarity and competitive ability of bread wheat (Triticum aestivum L.) and pea (Pisum sativum L.) in mixture. Agricoltura Mediterranea 123, 114-121.

Paolini R, Principi M, Froud-Williams RJ, Del Puglia S \& Biancardi E (1999) Competition between sugarbeet and Sinapis arvensis and Chenopodium album, as affected by timing of nitrogen fertilization. Weed Research 39, 425-440.

Paul JW \& Beauchamp EG (1993) Nitrogen availability for corn in soils amended with urea, cattle slurry, and solid and composted manures. Canadian Journal of Soil Science 73, 253-266.

Pearson CJ \& Ison RL (1997) Agronomy of Grassland Systems (eds CJ Pearson \& RL Ison). Cambridge University Press, Cambridge, UK.

Penfold CM, Miyan MS, Reeves TG \& Grierson IT (1995) Biological farming for sustainable agricultural production. Australian Journal of Experimental Agriculture 35, 849-856.

Peruzzi A, Bàrberi P, Ginanni M, Raffaelli M \& Silvestri N (1997) Prove sperimentali di controllo meccanico delle infestanti del frumento mediante erpice strigliatore. In: Proceedings VI Convegno Nazionale di Ingegneria Agraria, Ancona, Italy, 669-678 (in Italian with English abstract).

Putnam AR (1988) Allelochemicals from plants as herbicides. Weed Technology 2, 510-518.

QASEM JR \& Hill TA (1989) On difficulties with allelopathy methodology. Weed Research 29, 345-347.

RAsmussen J (1992) Testing harrows for mechanical control of annual weeds in agricultural crops. Weed Research 32, 267-274.

RASMUSSEN K (2000) Can slurry injection improve the selectivity of weed harrowing in cereals? In: Proceedings 4th Workshop of the EWRS Working Group on Physical and Cultural Weed Control, Elspeet, The Netherlands, 33-34. 
Rasmussen J \& Ascard J (1995) Weed control in organic farming systems. In: Proceedings 13th Long Ashton International Symposium, Ecology and Integrated Farming Systems (eds DM Glen, MP Greaves \& HM Anderson), 49-67. John Wiley \& Sons, Chichester, UK.

RASMuSSEN K \& RASMussen J (2000) Barley seed vigour and mechanical weed control. Weed Research 40, 219-230.

Rasmussen IA, Askegaard M \& Olesen JE (1999) Plant protection in organic crop rotation experiments for grain production. In: Proceedings International Workshop on Designing and Testing Crop Rotations for Organic Farming, Borris, Denmark, 321-330.

Rydberg NT \& Milberg P (2000) A survey of weeds in organic farming in Sweden. Biological Agriculture and Horticulture 18, 175-185.

SANCES FV \& Ingham ER (1997) Conventional and organic alternatives to methyl bromide on California strawberries. Compost Science and Utilization 5, 23-37.

SArtorato I, Zuin MC \& Zanin G (2001) I reflui zootecnici come veicolo d'infestazione dei campi coltivati. L'Informatore Agrario 7, 31-36 (in Italian).

Sauerborn J, Linke KH, Saxena MC \& Koch W (1989) Solarization: a physical control method for weeds and parasitic plants (Orobanche spp.) in Mediterranean agriculture. Weed Research 29, 391-397.

SEIGLer DS (1996) Chemistry and mechanisms of allelopathic interactions. Agronomy Journal 88, 876-885.

Soil Association (2000) The Biodiversity Benefits of Organic Farming. Soil Association, Bristol, UK.

Spandl E, Durgan BR \& Forcella F (1998) Tillage and planting date influence foxtail (Setaria spp.) emergence in continuous spring wheat (Triticum aestivum). Weed Technology 12, 223-229.

Stevenson FC, Légère A, Simard RR, Angers DA, Pageau D \& LAFOnd J (1998) Manure, tillage, and crop rotation: effects on residual weed interference in spring barley cropping systems. Agronomy Journal 90, 496-504.

Stolton S, Geier B \& McNeely JA (2000) Introduction: the relationship between nature conservation, biodiversity and organic agriculture. In: Proceedings International Workshop: the Relationship Between Nature Conservation, Biodiversity and Organic Agriculture (eds S Stolton, B Geier \& JA McNeely), Vignola, Italy, 5-12. IFOAM, Tholey, Germany.

Stonehouse DP, Weise SF, Sheardown T, Gill RS \& Swanton CJ (1996) A case study approach to comparing weed management strategies under alternative farming systems in Ontario. Canadian Journal of Agricultural Economics-Revue Canadienne d'Economie Rurale 44, 81-99. Swanton CJ \& WeISE SF (1991) Integrated weed management: the rationale and approach. Weed Technology 5, 657-663.
Teasdale JR \& Mohler CL (1993) Light transmittance, soil temperature, and soil moisture under residue of hairy vetch and rye. Agronomy Journal 85, 673-680.

Teasdale JR \& Mohler CL (2000) The quantitative relationship between weed emergence and the physical properties of mulches. Weed Science 48, 385-392.

Tompkins DK, Chaw D \& Abiola AT (1998) Effect of windrow composting on weed seed germination and viability. Compost Science and Utilization 6, 30-34.

VAN DER WeIDE R \& BLEeKer P (2000) Status of physical weed control in arable production and vegetables in The Netherlands. In: Proceedings 4th Workshop of the EWRS Working Group on Physical and Cultural Weed Control, Elspeet, The Netherlands, 1-2.

VereiJKen PH, Visser RP \& KLoen H (1998) Innovatie van de EKO-Akkerbouw en Groenteteelt Met 10 Voorhoedebedrijven (1991-97). Rapport no. 88. AB-DLO, Wageningen, The Netherlands (in Dutch).

Waller GR, Feng MC \& Fuji Y (1999) Biochemical analysis of allelopathic compounds: plants, microorganisms, and soil secondary metabolites. In: Principles and Practices in Plant Ecology (eds Inderjit, KMM Dakshini \& CL Foy), 75-98. CRC Press, Boca Raton, FL, USA.

WeIDENHAMER JD (1996) Distinguishing resource competition and chemical interference: overcoming the methodological impasse. Agronomy Journal 88, 866-875.

Welsh JP, Phillips L, Bulson HAJ \& Wolfe M (1999) Weed control strategies for organic cereal crops. In: Proceedings 1999 Brighton Conference - Weeds, Brighton, UK, 945-950.

Weston LA (1996) Utilization of allelopathy for weed management in agroecosystems. Agronomy Journal 88, 860-866.

Wilson BJ, Wright KJ \& Butler RC (1993) The effect of different frequencies of harrowing in the autumn or spring on winter wheat, and on the control of Stellaria media (L.) Vill., Galium aparine L. and Brassica napus L. Weed Research 33, 501-506.

Yenish JP, Worsham AD \& Chilton WS (1995) Disappearance of DIBOA-glucoside, DIBOA, and BOA from rye (Secale cereale L.) cover crop residue. Weed Science 43, 18-20.

Zanin G, Otto S, Riello L \& Borin M (1997) Ecological interpretation of weed flora dynamics under different tillage systems. Agriculture Ecosystems and Environment 66, 177-188.

ZimDAHL RL (1993) Weed biology: reproduction and dispersal. In: Fundamentals of Weed Science (ed. RL Zimdahl), 59-89. Academic Press, San Diego, CA, USA.

ZIMDAHL RL (1995) Weed science in sustainable agriculture. American Journal of Alternative Agriculture 10, 138-142. 